\title{
Original article \\ Effects of a full season on stabilometric Parameters of team handball elite athletes
}

\author{
Paulo H. Marchetti \\ Methodist University of Piracicaba, Brazil \\ Maria Isabel V. Orselli \\ University of São Paulo, Brazil \\ Lúcio M. S. Martins \\ Vita Institute, Brazil \\ Marcos Duarte \\ Federal University of $A B C$, Brazil
}

\begin{abstract}
It is unclear whether athletes change their postural control over the course of a full sport season, or become more asymmetrical with respect to their neuromuscular performance over the same period. The aim of this study was to investigate the effects of a full sport season on the postural control of team handball elite athletes. Ten healthy, elite male team handball players performed bipodal standing (BP) and right and left unipodal standing (UP) during 30s. We used the RMS and speed of the center of pressure to describe postural sway. For the BP task, the sway was lower at the end of the season $(p<0.005)$. For the UP tasks, the sway was lower at the end of the season only for the non-dominant $\operatorname{limb}(p<0.001)$. Differences between limbs were observed only at the end of the season $(p<0.03)$. In conclusion, a full team handball season did not lead to deterioration of the athletes' postural control, but by the end of the season, the athletes were more asymmetrical.
\end{abstract}

Keywords: exercise performance, biomechanics, motor control, postural stability, stabilometry, physical performance

Resumo - “Efeitos da temporada completa em parâmetros estabilométricos em atletas de handebol de elite.” Não é claro na literatura científica se atletas mudam seu controle postural ao longo de uma temporada esportiva, ou mesmo se tornam mais assimétricos em relação ao seu desempenho neuromuscular durante o mesmo período. O objetivo deste estudo foi investigar os efeitos de uma temporada esportiva completa no controle postural de atletas de elite do handebol. Dez jogadores de elite de handebol, saudáveis, realizaram a tarefa de postura ereta quieta bipodal (BP) e unipodal direito e esquerdo durante 30 segundos. Foi utilizada a RMS e a velocidade do centro de pressão para descrever a oscilação postural. Para a tarefa de BP, a oscilação foi menor após a temporada esportiva $(p<0,005)$. Para as tarefas unipodais, a oscilação foi menor após temporada esportiva apenas para o membro não dominante $(p<0,001)$. Apenas após a temporada, foram observadas diferenças entre os membros $(p<0,03)$. Em conclusão, uma temporada esportiva para o handebol não levou à deterioração do controle postural dos atletas, entretanto no final da temporada, os atletas apresentaram-se mais assimétricos.

Palavras-chave: desempenho do exercício, biomecânica, controle motor, estabilidade postural, desempenho físico

Resumen - “Efectos de la temporada completa en parámetros estabilométricos en atletas de balonmano de élite.” No está claro en la literatura científica si los atletas cambian su control postural a lo largo de una temporada deportiva o incluso si llegan a ser más asimétricas en relación con su rendimiento neuromuscular durante el mismo período. El objetivo de este estudio fue investigar los efectos de una temporada deportiva completa en control postural de deportistas de elite de balonmano. Diez jugadores de balonmano de élite, sanos, llevaron a cabo la tarea de la tranquilidad de la postura de pie bipodal (BP) y unipodal izquierda y derecha durante 30 segundos. RMS fue utilizado y la velocidad del centro de presión para describir el balanceo postural. Para la tarea de BP, la oscilación fue menor después de la temporada de deportes $(p<0,005)$. Para unipodais las tareas, la oscilación fue menor después de la temporada deportiva para el miembro no dominante $(p<0,001)$. Solamente después de la temporada, se observaron diferencias entre los miembros $(p<0,03)$. En conclusión, una temporada de deportes para el balonmano no conduce al deterioro del control postural de los atletas, sin embargo al final de la temporada, los atletas presentaron más asimétrica.

Palabras clave: rendimiento del ejercicio, biomecánica, control del motor, estabilidad postural, rendimiento físico 


\section{Introduction}

The control of posture while standing is a fundamental task achieved by a complex integration of the neuromuscular, vestibular, visual, somatosensory systems (Horak, 2006; Jancová, 2008). Particularly, practicing a sport enhances the ability to use the control of posture by athletes, mainly because of the improvement of somatosensory and otolithic information (Hrysomallis, 2011; Paillard et al., 2006). Several studies have shown that the control of one's posture is dependent on the type of sport being practiced (Bressel, Yonker, Kras, \& Heath, 2007; Marchetti, Hartigan, \& Duarte, 2012; Paillard et al., 2006; Perrin, Deviterne, Hugel, \& Perrot, 2002; Schwesig et al., 2009; Vuillerme et al., 2001). For example, athletes practicing judo, and dancers, demonstrated better postural control (static and dynamic) than non-athletes (Perrin et al., 2002), while in the study by Vuillerme et al. (2001), gymnasts demonstrated a better balance when compared to a control group (soccer, team handball, and tennis players). The study by Bressel et al. (2007) analyzed three different stance variations (double leg, single leg and tandem leg) on two surfaces (stiff and pliable) in different sports. The study concluded that gymnasts and soccer players did not differ with respect to static and dynamic balance, while basketball players demonstrated inferior balance. Schwesig et al. (2009) investigated the influence of several sports (team handball, gymnastics, swimming, and shooting) on postural control, and observed that athletes engaged in sports with high postural demands presented a greater postural control. Paillard et al. (2006) showed differences in postural performance and postural strategy between soccer players at different levels of competition (national and regional), where players at a national level were more stable than regional-level players, and used proprioception and vision information differently.

Although improvements in postural control were observed only in challenging experimental conditions, for any given sport modality (i.e. soccer, team handball, basketball), the effect of a full season is unknown. On one hand, one could argue that given athletes' consistent training and practice routines, their postural control would improve by the end of the season. Nevertheless, it is well known that acute neuromuscular fatigue has a strong negative effect on postural control (Augustsson et al., 2006; Berger, Regueme, \& Forestier, 2010; Gribble \& Hertel, 2004a, 2004b; Marchetti et al., 2012; Marchetti, Orselli, \& Duarte, 2013; Vuillerme, Sportbert, \& Pinsault, 2009; Yaggie \& McGregor, 2002) thus, one could argue that the postural control of athletes would in fact deteriorate by the end of a sport season. Furthermore, after an entire season, athletes could show some exhaustion due to the heavy load of training, particularly in the case of elite athletes, causing possible injuries (i.e. ankle sprains) or muscle imbalances (Fu \& Hui-Chan, 2005; Leanderson, Eriksson, \& Wykman, 1993; P. P. Perrin, Bene, \& Perrin, 1997).

Another related issue of sport training is the development of neuromuscular asymmetry. It is generally recognized that the best performance in whole body tasks such as postural control is achieved by a symmetrical musculoskeletal system - relative to the two sides of the body (Cates \& Cavanaugh, 2009; Hickey et al., 2009; Paillard et al., 2006). However, practicing a sport may exacerbate neuromuscular asymmetry, where an athlete may exercise one side of the body more often or intensely than the other (e.g., when consistently jumping or kicking with the same leg during matches or training sessions). It is possible that athletes will be more asymmetrical with respect to their neuromuscular performance after a season of play, which could have a negative effect on the execution of motor tasks, particularly postural control. Unbalanced functional skills may increase risk for injury in athletes (Hewett et al., 2005; Hickey et al., 2009; Klein, 1970).

Therefore, the purpose of the present study was to investigate the effects of a full sport season in the postural control of team handball elite athletes. We hypothesize that (1) after a full season, athletes would show deterioration signs of their postural control, and that (2) they would be more asymmetrical during their performance in postural control tasks.

\section{Methods}

\section{Participants}

Ten healthy, elite male, team handball players took part in the study (mean \pm SD age: $24 \pm 4$ years; height: $186 \pm 5 \mathrm{~cm}$; and weight: $90 \pm 4 \mathrm{~kg}$ ). All team handball players that took part in this study were from the same team (all positions), of national level, and none of them ceased to play for more than three weeks during the year before entering the study. All participants performed the following monthly training volume (5 days per week): physical conditioning $(12,16,15,14,9$ sessions per month, respectively); technical training $(3,16,14,15,17$ sessions per month, respectively); strength training $(8,6,9,8,4$ sessions per month, respectively); games $(0,5,4,6,8$ per month, respectively). Individuals who participated in this study had no previous surgery of lower extremities, no history of injury with residual symptoms (pain, "giving-away" sensations) in the lower extremities in the last year, and had no sign of leg length discrepancy (distance from the anterior superior iliac spine to the superior surface of the most prominent aspect of the medial malleolus larger than one centimeter). This study was approved by the local ethics committee of the University of São Paulo, and all volunteers gave their written informed consent before participation.

\section{Procedures}

Prior to data collection, participants were asked which leg was preferred for kicking a ball. Their preferred kicking leg was considered the dominant leg (Maulder \& Cronin, 2005). Participants were tested at the beginning (the day prior the beginning of the training season) and at the end of the season (two days after the last game). The sport season lasted five months. For each period of the season, participants performed three postural tasks: bipodal standing, and right- and left-footed standing.

During the bipodal standing task, participants were asked to select a comfortable standing position with their feet apart approximately the length of their hip width, and with their arms crossed at their chest. Participants stood with each foot on a 
different force plate (OR6, AMTI, USA). During the unipodal standing tasks, participants were instructed to lift one leg at the level of the medial malleolus of their opposite leg, and asked to keep this position with their arms crossed at their chest. In both tasks, participants were instructed to stand upright as still as possible while looking straight ahead at a point about two meters away at eye level. All participants remained barefoot during the experiment. Each participant performed a total of three trials of standing for 30 seconds with 60 seconds of rest between the tasks. All trials were randomized. We recorded the ground reaction forces and moments from each force plate at a $300 \mathrm{~Hz}$ sampling frequency, and used these to calculate the center of pressure (COP) displacement for each force plate (limb). The resultant COP displacement for the whole body in the anteroposterior (a-p) and mediolateral (m-1) directions was calculated as follow: $\mathrm{COP}=(\mathrm{COP} 1 * \mathrm{Fz} 1+\mathrm{COP} 2 * \mathrm{Fz} 2 /(\mathrm{Fz} 1+\mathrm{Fz} 2)$, where $\mathrm{Fz}$ is the ground reaction force in the vertical direction and the indexes 1 and 2 refer to the different force plates.

\section{Data analysis}

All data were analyzed with a customized program written in Matlab (Mathworks Inc., EUA). To remove the offset of the COP data, the mean was subtracted from each time series. For the standing task, the COP data were filtered with a 4th-order $10 \mathrm{~Hz}$ low-pass zero-lag Butterworth filter. With the data of the bipodal standing task, we computed the following variables in the anterior-posterior (a-p) and medial-lateral (m-l) directions (Duarte \& Freitas, 2010; Peterka, Gianna-Poulin, Zupan, \& Merfeld, 2004): COP root-mean squared (RMS), COP Speed and frequency. For the unipodal standing task, the same analyses were conducted with the data from each lower limb.

The COP speed was calculated by dividing the COP resultant displacement by the total 30 -second period of the trial in each direction (a-p and $m-1)$. The frequency of the COP displacement in each direction (a-p and $\mathrm{m}-1$ ) was calculated by determining the frequency at which less than $80 \%$ of the COP spectral power occurred. The $80 \%$ cut-off value was chosen based on previous work (Baratto, Morasso, Re, \& Spada, 2002) that suggests this value is a superior discriminator for the COP data compared to other spectral measurements. The power spectral density was estimated by the Welch periodogram of the detrended data, with a resolution of $0.039 \mathrm{~Hz}$ (Baratto et al., 2002; Duarte \& Freitas, 2010).

\section{Statistical analyses}

Normality and homogeneity of variances of the data were confirmed by the Shapiro-Wilk and Levene tests, respectively. Paired $t$-tests were used to compare mean values for all variables at both sport season periods (pre- and post-season): COP Speed (a-p and $\mathrm{m}-\mathrm{l}$ directions), COP RMS (a-p and $\mathrm{m}-\mathrm{l}$ directions), and median frequency (a-p and $\mathrm{m}-1$ directions).

For the dependent variables COP RMS (a-p and m-l directions), COP Speed (a-p and $\mathrm{m}-1$ directions) and frequency (a-p and m-1 directions), analyses of variance (ANOVAs) were employed with lower limbs (right and left) and periods (preseason and post-season) as repeated measure factors. Post-hoc comparisons were performed using the Sidak test. Cohen's formula for effect size (ES) was used and the results were based in the following criteria: $<0.25$ trivial effect; $0.25-0.50$ small effect; 0.50-1.0 moderate effect; and >1.0 large effect, as in recreationally resistance-trained according to Rhea (2004). An alpha of 5\% was used for all statistical tests.
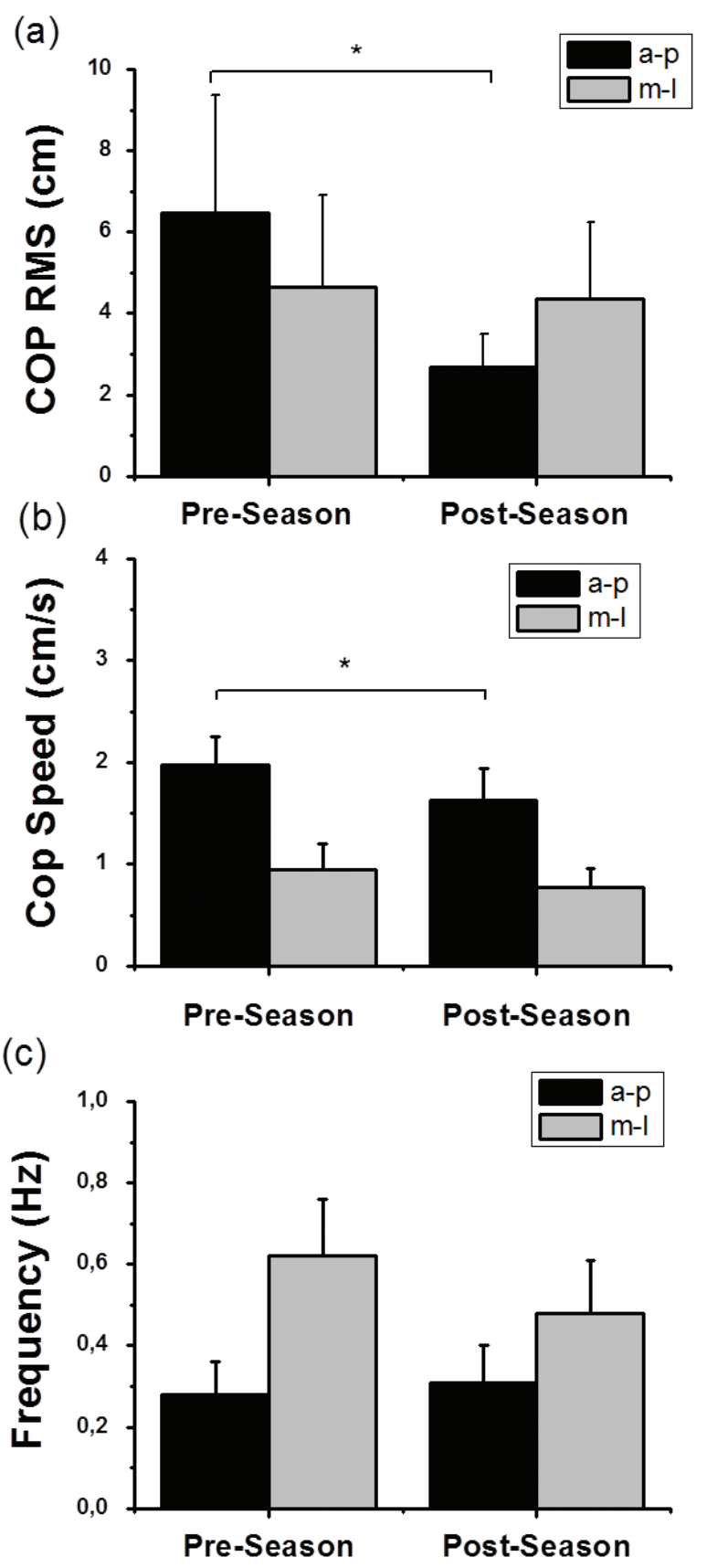

Figure 1. Mean \pm SD values for pre- and post-season during bipodal quiet standing of the following analyzed variables: (a) COP RMS (anterior-posterior and medial-lateral directions), (b) COP speed (anterior-posterior and medial-lateral directions), and (c) frequency (anterior-posterior and medial-lateral directions). $\left({ }^{*} p<0.05\right)$. 


\section{Results}

Figure 1 depicts the mean and standard deviation for preand post-season during bipodal quiet standing of the following variables: (a) COP RMS (anterior-posterior and medial-lateral directions) (b) COP speed (anterior-posterior and medial-lateral directions) and (c) frequency (anterior-posterior and medial-lateral directions). The results of the bipodal standing revealed significant differences between COP Speed (a-p) $(t \underline{9}=5.05, p=0.001)$ and COP RMS (a-p) $(t \underline{9}=6.67, p=0.004)$ at pre and post-season (effect size $=1.21$ and 3.3, respectively) (Figure 1).

Figure 2 depicts the mean and standard deviation for preand post-season during unipodal quiet standing of the following variables: (a) COP RMS (anterior-posterior and medial-lateral directions) (b) COP speed (anterior-posterior and medial-lateral directions) and (c) frequency (anterior-posterior and medial-lateral directions). The results of the ANOVA for unipodal standing revealed the main effects of pre/post-season on COP RMS (m-l) $\left(F_{3.27}=4.61, p=0.049\right)$, and COP Speed (a-p) $\left(F_{3,27}=18.5, p<0.001\right)$ and $(\mathrm{m}-\mathrm{l})\left(F_{3.27}=5.07, p=0.002\right)$. The results of the ANOVA for unipodal quiet standing revealed the main effects of lower limbs on COP RMS (a-p) $\left(F_{3,27}=9.88, p=0.024\right)$, and COP Speed (a-p) $\left(F_{3,27} 4.47, p=0.002\right)$ and $(\mathrm{m}-1)(p<0.001)$, and between pre- and post-season and the lower limbs on COP RMS (a-p) $\left(F_{3.27}=4.61\right.$, $p=0.034)$ and $(\mathrm{m}-\mathrm{l})\left(F_{3,27}=4.63, p=0.030\right)$, and COP Speed (a-p) $\left(F_{3,27}=9.26, p=0.003\right)$ and $(\mathrm{m}-1)\left(F_{3,27}=10.4, p=0.002\right)$.

Post-hoc analysis revealed significant differences between pre- and post-season, only in the non-dominant lower limb, for COP RMS (a-p) $(p<0.001)$ and $(\mathrm{m}-1)(p<0.001)$, and COP speed $(\mathrm{a}-\mathrm{p})(p<0.001)$ and $(\mathrm{m}-\mathrm{l})(p<0.001)($ effect size $=0.78,2.14$ and 2.57 , respectively). The post-hoc analysis showed significant differences between lower limbs, only in the post-season, on COP RMS (a-p) $(p=0.027)$ and $(\mathrm{m}-\mathrm{l})(p<0.001)$, and COP Speed $(\mathrm{a}-\mathrm{p})(p<0.001)$ and $(\mathrm{m}-\mathrm{l})(p<0.001)($ effect size $=1.08,1.31$, 4.40 and 2.28, respectively) (Figure 2).

\section{Discussion}

This study investigated the effects of a full season of activity on the postural control in team handball elite athletes. We chose variables that are considered the standard measures of balance while standing (Jancová, 2008; Riemann, Guskiewicz, $\&$ Shields, 1999). Our hypotheses were that (1), after a full season, athletes would demonstrate deterioration of their postural control, and that (2) they would be more asymmetrical with respect to their performance in postural control tasks.

Our evidence in this study did not support our first hypothesis. For the bipodal task we observed a lower COP RMS and COP Speed in the a-p direction (sagittal plane) indicating an improvement of the balance performance [i.e. considering the ability to minimize postural sway (Hrysomallis, 2011; Paillard et al., 2006; Zverev, 2006)]. These results may be related to high demand on stability during different side by side team handball skilled movements, for example, while maintaining a ball possession, passing, dribbling, throwing, resulting in changes of the balance control in this specific plane of motion (sagittal plane).
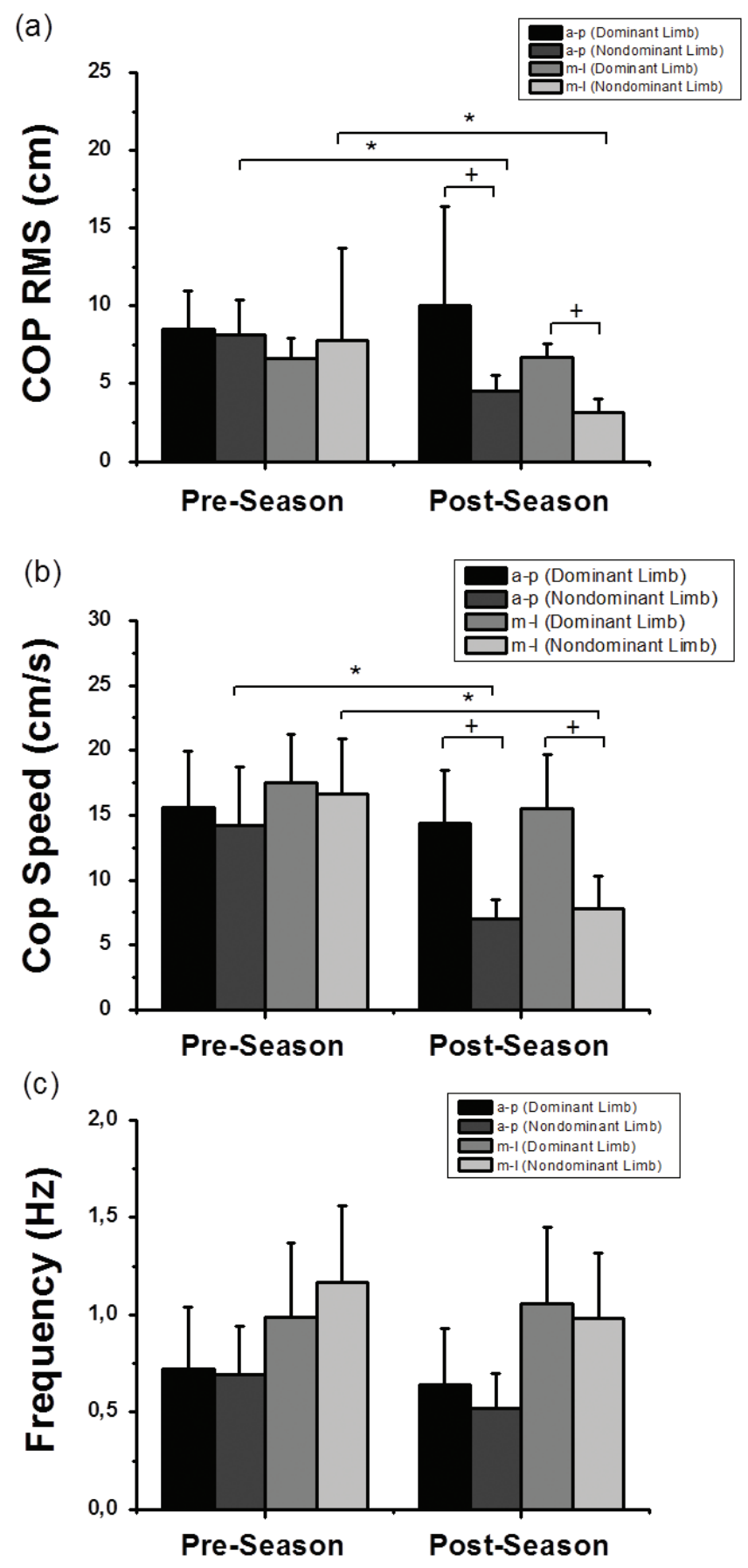

Figure 2. Mean \pm SD values for pre- and post-season during unipodal quiet standing of the following analyzed variables: (a) COP RMS (anterior-posterior and medial-lateral directions) (b) COP speed (anterior-posterior and medial-lateral directions) and (c) frequency (anterior-posterior and medial-lateral directions). Note: * indicates difference between season periods, $p<0.05$; ${ }^{+}$difference between lower limbs, $p<0.05$.

During the unipodal postural control evaluation, we observed a lower COP RMS and speed in the a-p and $m-1$ directions only for the non-dominant limb in the post-season period. For the most offensive conditions, the team handball players perform jumps and throws, and these tasks require a great neuromuscular 
stress in the non-dominant limb that remains on the ground or propelling vertical and horizontal displacements. So, during the season, we expected that these alterations in balance control are result of asymmetric and specific neuromuscular demands of the non-dominant limb.

The frequencies in both balance tasks (bipodal and unipodal) for the sagittal and frontal planes (a-p and m-l directions, respectively) were not different at the end of the season. Paillard et al. (2006) observed that the contribution of high and low frequencies were different between regional and national soccer players. On the other hand, in our study, differences may not have occurred in the postural strategy due to the high level of trainability of our participants.

Overall, our results suggest that the athlete group generally exhibited changes in the balance (postural stability) after the season compared to the pre-season period. Their improvement may be the consequence of the high and repetitive demands of the training and games during the season. Such experience may have influenced the athlete's ability to prioritize proprioceptive and visual stimulus, and probably, helped to improve neuromuscular parameters [i.e. strength, coordination, power (Hrysomallis, 2011)]. In addition to that, they could have decreased the proportions of balance-related muscle activation (Taube, Gruber, \& Gollhofer, 2008). Therefore, repetitive experience of high-level athletes might improve balance ability due to neurological adaptations (i.e. reducing visual inputs and relying on the other balance sensors, such as proprioception). Then, the reduced visual input may allow to pay more attention to other information required during the sport activity (Taube et al., 2008).

Based on the performance variation between legs (asymmetrical behavior), our results confirmed our second hypothesis, that the athlete group would demonstrate a more asymmetrical pattern after the season. In fact, the athlete group presented higher levels of asymmetry between legs for COP RMS (a-p and $\mathrm{m}-\mathrm{l}$ ) and COP speed (a-p and $\mathrm{m}-\mathrm{l}$ ) only after the season. For COP RMS and COP Speed, we observed an increase in the postural performance only for the non-dominant limb. Possible explanations for these results may be the physical demands (Hugel, Cadopi, Kohler, \& Perrin, 1999; Oliver \& Di Brezzo, 2009; Paillard \& Noé, 2006; Vuillerme et al., 2001) and specific sensorimotor challenges (Bressel et al., 2007) typical for this kind of sport. Team handball is an open-skill team sport, strongly dependent on a player's ability to move quickly, jump unilaterally, and throw the ball while coordinating lower and upper limb movements (Chelly, Hermassi, \& Shephard, 2010; Gorostiaga, Granados, Ibanez, \& Gonzales-Badillo, 2006). Several movements during the game are asymmetrical (i.e. jumps, dribbling), which could produce differences in the neuromuscular control (Ball, Stock, \& Scurr, 2010; Hickey et al., 2009). Therefore, it is possible that these athletes have developed specific balance skills that differed between lower limbs. Several authors claim that the preferred leg is often that a person uses to control an object, or in the beginning of a movement, while the other leg is preferred to support the body or propel (Sadeghi, Allard, Prince, \& Labelle, 2000). In our study, non-dominant leg is related to support the body allowing the contra-lateral limb to kick a ball, therefore it is expected better postural improvement in this limb when compared to the dominant limb.
We recognize that this study has some limitations. (1) We did not exclude team handball players with a previous history of lower extremity ankle sprains. We assumed that players, who had these injuries and showed no residual symptoms for more than a year, did not differ significantly from the other players (McGuine, Greene, Best, \& Leverson, 2000; Wang, Chen, Shiang, Jan, \& Lin, 2006); (2) We have no control group in this study. However, the inclusion of a control group consisting of high-level athletes required not to practice the sport for an entire season would be impossible and unethical, as withholding training would be detrimental to the players' development; (3) we analyzed only one specific sport with very specific demands for postural control, and our results cannot be generalized to other sports.

Previous studies have shown that the majority of injuries during sports occurred in the lower limbs, usually during jumping, landing and dodging players. In such cases, they displayed a high variation of postural stability outcomes and were more likely to suffer injuries during sport sessions (Hickey et al., 2009; Killen, Gabbett, \& Jenkins, 2010; Wang et al., 2006). Sport researchers, strength and conditioning coaches, and athletic trainers could benefit from a known relationship between postural performance, lower limbs asymmetries and injuries (i.e. ankle sprains and noncontact anterior cruciate ligament) as a consequence of training throughout a sport season (Emery, Sarah Rose, McAllister, \& Meeuwise, 2007; Fu \& Hui-Chan, 2005; Olsen, Myklebust, \& Engebrestsen, 2004). The relationship between asymmetries and injuries was, however, not the focus of this study, and may be considered for future studies.

\section{Conclusion}

In conclusion, although specific sports neuromuscular demands may alter the postural control of the lower limbs at the end of a full season, team handball athletes did not demonstrate such effects in their postural control, and they were more asymmetrical in the non-dominant limb.

\section{References}

Augustsson, J., Thomee, R., Linden, C., Folkesson, M., Tranberg, R., \& Karlsson, J. (2006). Single-leg hop testing following fatiguing exercise: reliability and biomechanical analysis. Scandinavian Journal of Medicine \& Science in Sports, 16(2), 111-120.

Ball, N. B., Stock, C. G., \& Scurr, J. C. (2010). Bilateral contact ground reaction forces and contact times during plyometric drop jumping. Journal of Strength and Conditioning Research, 24(10), 2762-2769.

Baratto, L., Morasso, P. G., Re, C., \& Spada, G. (2002). A new look at posturographic analysis in the clinical context: sway-density versus other parameterization techniques. Motor Control, 6(3), 246-270.

Berger, L., Regueme, S. C., \& Forestier, N. (2010). Unilateral lower limb muscle fatigue induces bilateral effects on undisturbed stance and muscles EMG activities. Jornal of Electromyography and Kinesiology, 20(5), 947-952.

Bressel, E., Yonker, J. C., Kras, J., \& Heath, E. M. (2007). Comparison of static and dynamic balance in female collegiate soccer, basketball, and gymnastics athletes. Journal of Athletic Training., 42(1), 42-46. 
Cates, W., \& Cavanaugh, J. (2009). Advances in Rehabilitation and performance testing. Clinical Journal of Sport Medicine, 28, 63-76.

Chelly, M. S., Hermassi, S., \& Shephard, R. J. (2010). Relationships between power and strength of the upper and lower limb muscles and throwing velocity in male handball players. Journal of Strength and Conditioning Research, 24(6), 1480-1414-1487.

Duarte, M., \& Freitas, S. M. F. (2010). Revision of posturography based on force plate for balance evaluation. Revista Brasileira de Fisioterapia, 14(3), 183-192.

Emery, C. A., Sarah Rose, M., McAllister, J. R., \& Meeuwise, W. H. (2007). A prevention strategy to reduce the incidence of injury in high school basketball: a cluster randomized controlled trial. Clinical Journal of Sport Medicine, 17(1), 17-24.

Fu, A. S. N., \& Hui-Chan, C. W. Y. (2005). Ankle joint proprioception and postural control in basketball players with bilateral ankle sprains. The American Journal of Sports Medicine, 33(8), 1174-1182.

Gorostiaga, E. M., Granados, C., Ibanez, J., \& Gonzales-Badillo, J. (2006). Effects of an entire season on physical fitness changes in elite male handball players. Medicine \& Science in Sports \& Exercise, 38(2), 357-366.

Gribble, P. A., \& Hertel, J. (2004a). Effect of hip and ankle muscle fatigue on unipedal postural control. Journal of Electromyography and Kinesiology, 14(6), 641-646.

Gribble, P. A., \& Hertel, J. (2004b). Effect of lower-extremity muscle fatigue on postural control. Archives of Physical Medicine and Rehabilitation, 85(4), 589-592.

Hewett, T. E., Myer, G. D., Ford, K. R., Heidt, R. S., Colosimo, A. J., McLean, S. G., Succop, P. (2005). Biomechanical measures of neuromuscular control and valgus loading of the knee predict anterior cruciate ligament injury risk in female athletes: A prospective study. The American Journal of Sports Medicine, 33, 492-501.

Hickey, K. C., Quatman, C. E., Myer, G. D., Ford, K. R., Brosky, J. A., \& Hewett, T. E. (2009). Methodological report: dynamic field tests used in an NFL combine setting to identify lower-extremity functional asymmetries. Journal of Strength and Conditioning Research, 23(9), 2500-2506.

Horak, F. B. (2006). Postural orientation and equilibrium: what do we need to know about neural control of balance to prevent falls? Age and Ageing, 35.

Hrysomallis, C. (2011). Balance ability and athletic performance. Sports Medicine, 41(3), 221-232.

Hugel, F. M., Cadopi, M., Kohler, F., \& Perrin, P. (1999). Postural control of ballet dancers: a specific use of visual input for artistic purposes. International Journal Sports Medicine, 20(2), 86-92.

Jancová, J. (2008). Measuring the balance control system - Review. Acta Medica, 51(3), 129-137.

Killen, N. M., Gabbett, T. J., \& Jenkins, D. G. (2010). Training loads and incidence of injury during the preseason in professional rugby league players. Journal of Strength and Conditioning Research, 24(8), 2079-2084.

Klein, K. K. (1970). Asymmetries in the pelvis and legs and their implications in knee injury. American Corrective Therapy Journal, 24, 93-95.

Leanderson, J., Eriksson, E., \& Wykman, A. (1993). Ankle sprain and postural sway in basketball players. Knee Surgery,Sports Traumatology,Arthroscopy, 1(3), 203-205.

Marchetti, P. H., Hartigan, E. H., \& Duarte, M. (2012). Comparision of the postural control performance of collegiate basketball players and nonathletes. Athletic Training \& Sports Health Care, 4(6), 251-256.

Marchetti, P. H., Orselli, M. I., \& Duarte, M. (2013). The effects of uniand bilateral fatigue on postural and power tasks. Jounal of Applied Biomechanics, 29(1), 44-48. doi: http://journals.humankinetics. $\mathrm{com} / \mathrm{jab}$-in-press/jab-in-press/the-effects-of-uni--and-bilateralfatigue-on-postural-and-power-tasks
Maulder, P., \& Cronin, J. (2005). Horizontal and vertical jump assessment: reliability, symmetry, discriminative and predictive ability. Physical Therapy in Sport, 6(2), 74-82. doi: 10.1016/j. ptsp.2005.01.001.

McGuine, T. A., Greene, J. J., Best, T., \& Leverson, G. (2000). Balance as a predictor of ankle injuries in high school basketball players. Clinical Journal of Sport Medicine, 2000(10), 4.

Oliver, G. D., \& Di Brezzo, R. (2009). Functional balance training in collegiate women athletes. Journal of Strength and Conditioning Research, 23(7), 2124-2129.

Olsen, O., Myklebust, G., \& Engebrestsen, L. (2004). Injury mechanisms for anterior cruciate ligament injuries in team handball. The American Journal of Sports Medicine, 32(4), 1002-1012.

Paillard, T., \& Noé, F. (2006). Effect of exepertise and visual contribution on postural control in soccer. Scandinavian Journal of Medicine \& Science in Sports, 16(5), 345-348.

Paillard, T., Noé, F., Rivière, T., Marion, V., Montoya, R., \& Dupui, P. (2006). Postural performance and strategy in the unipedal stance of soccer players at different levels of competition. Journal of Athletic Training, 41(2), 172-176.

Perrin, P., Deviterne, D., Hugel, F., \& Perrot, C. (2002). Judo, better than dance, develops sensorimotor adaptatibilities involved in balance control. Gait \& Posture, 15(2), 187-194.

Perrin, P. P., Bene, M. C., \& Perrin, C. A. (1997). Ankle trauma significantly impairs posture control a study in basketball players and controls. International Journal of Sports Medicine, 18(5), 387-392.

Peterka, R. J., Gianna-Poulin, C. C., Zupan, L. H., \& Merfeld, D. M. (2004). Origin of orientation-dependent asymmetries in vestibulo-ocular reflexes evoked by caloric stimulation. J Neurophysiol, 92(4), 2333-2345.

Rhea, M. R. (2004). Determining the magnitude of treatment effects in strength training research through the use of the effect size. Journal of Strength and Conditioning Research, 18(4), 918-920. doi: 10.1519/14403.1

Riemann, B. L., Guskiewicz, K. M., \& Shields, E. W. (1999). Relationship between clinical and forceplate measures of postural stability. Journal of Sport Rehabilitation, 8, 71-82.

Sadeghi, H., Allard, P., Prince, F., \& Labelle, H. (2000). Symmetry and limb dominance in able-bodied gait: a review. Gait \& Posture, 12(1), 34-45.

Schwesig, R., Kluttig, A., Leuchte, S., Becker, S., Schimidt, H., \& Esperer, H. D. (2009). The impact of different sports on posture regulation. Sportverletz Sportschaden, 23(3), 148-154.

Taube, W., Gruber, M., \& Gollhofer, A. (2008). Spinal and supraspinal adaptations associated with balance training and their functional relevance. Acta Physiologica, 193, 101-116.

Vuillerme, N., Danion, F., Marin, L., Boyadjian, A., Prieur, J. M., Weise, I., \& Nougier, V. (2001). The effect of expertise in gymnastics on postural control. Neuroscience Letters, 303(2), 83-86.

Vuillerme, N., Sportbert, C., \& Pinsault, N. (2009). Postural adaptation to unilateral hip muscle fatigue during human bipedal standing. Gait \& Posture, 30(1), 122-125.

Wang, H. K., Chen, C. H., Shiang, T. Y., Jan, M. H., \& Lin, K. H. (2006). Risk-factor analysis of high school basketball-player ankle injuries: a prospective controlled cohort study evaluating postural sway, ankle strength, and flexibility. Archives of Physical Medicine and Rehabilitation, 87(6), 821-825.

Yaggie, J. A., \& McGregor, S. J. (2002). Effects of isokinetic ankle fatigue on the maintenance of balance and postural limits. Archives of Physical Medicine and Rehabilitation, 83(2), 224-228.

Zverev, Y. P. (2006). Spatial parameters of walking gait and footedness. Annals of Human Biology, 33(2), 161-176. 


\section{Authors' note}

Paulo H. Marchetti is with the Methodist University of Piracicaba, Piracicaba, São Paulo, Brazil and Faculty of Physical Education (YMCA), Sorocaba, São Paulo, Brazil.

Maria Isabel V. Orselli is with the Institute of Physics, University of São Paulo, Brazil.

Lúcio M. S. Martins is with the Vita Institute, Brazil.

Marcos Duarte is with the Biomedical Engineering at the Federal University of $\mathrm{ABC}$, Brazil.

\section{Corresponding author:}

Paulo H. Marchetti

Rodovia do Açúcar Km 156, Bloco 7, Sala 32, Taquaral, Piracicaba, SP, Brazil. 13400-911.

E-mail: dr.pmarchetti@gmail.com

Manuscript received on July 22, 2013

Manuscript accepted on January 11, 2014

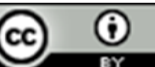

